\title{
Primary adenosquamous carcinoma of the liver: a case report
}

\author{
Kyung Han Nam, and Ji Yeon Kim \\ Department of Pathology, Haeundae Paik Hospital, Inje University College of Medicine, Busan, Korea
}

Adenosquamous carcinoma of the liver is a rare variant of cholangiocarcinoma. It is known to be a highly aggressive tumor with a poor prognosis, but its pathogenesis remains unclear owing to limited data in the literature. We report a case of 56-year-old woman who presented with a 1-week history of epigastric pain. Magnetic resonance imaging revealed a $6.5-\mathrm{cm}$ ill-defined mass with low signal intensity in the left lobe of the liver, which was suspicious of cholangiocarcinoma. The patient underwent left hemihepatectomy. Microscopically, the tumor consisted of malignant glandular and squamous components and staged as pT2aN1. Despite postoperative chemoradiation, the patient had recurrence 8 months after surgery. (Clin Mol Hepatol 2016;22:503-508)

Keywords: Adenosquamous carcinoma; Liver; Cholangiocarcinoma; Pathology

\section{INTRODUCTION}

Adenosquamous carcinoma (ASC) consists of malignant glandular and squamous components. Primary ASC of the liver is very rare. It has been considered as a subtype of cholangiocarcinoma, accounting for approximately $2 \%$ to $3 \%$ of all cases. The literature on this tumor has been limited because most published reports have been represented as case reports or studies of small cases series. $^{1-4}$ The diagnoses of majority of the reported cases were made by surgical resection or autopsy owing to difficult early detection, advance stage at the time of diagnosis, and low rate of curative resection. ${ }^{1-3}$ Although the characteristics of the tumor are hard to clarify owing to limited data in the literature, several studies have noted that ASC was a more aggressive neoplasm with a worse prognosis compared with the common cholangiocarcinoma. ${ }^{1,3,4}$ Furthermore, the pathogenesis of hepatic ASC re- mains unclear. In this study, we present a case of resected primary ASC of the liver with a common bile duct (CBD) stone and review of the Korean literature.

\section{CASE REPORT}

A 56-year-old woman presented to a local hospital with a 1-week history of right epigastric pain. She reported no weight loss or remarkable past medical problems. She had no history of smoking or alcohol abuse and no specific family history of cancer. Physical examination revealed severe tenderness over the epigastric area but no palpable mass on the abdomen. However, laboratory results revealed elevated serum alkaline phosphatase (169 U/L; normal range, 35-104 U/L) and gamma-guanosine triphosphate (96 IU/L; normal range, 8-48 U/L). The levels of serum aspartate

\section{Abbreviations:}

ASC, adenosquamous carcinoma; CBD, common bile duct

\section{Corresponding author : Kyung Han Nam}

Department of Pathology, Haeundae Paik Hospital, Inje University College of Medicine, 875 Haeun-daero, Haeundae-gu, Busan 48108, Korea

Tel: +82-51-797-3100, Fax: +82-51-797-3101

E-mail:H00300@paik.ac.kr 

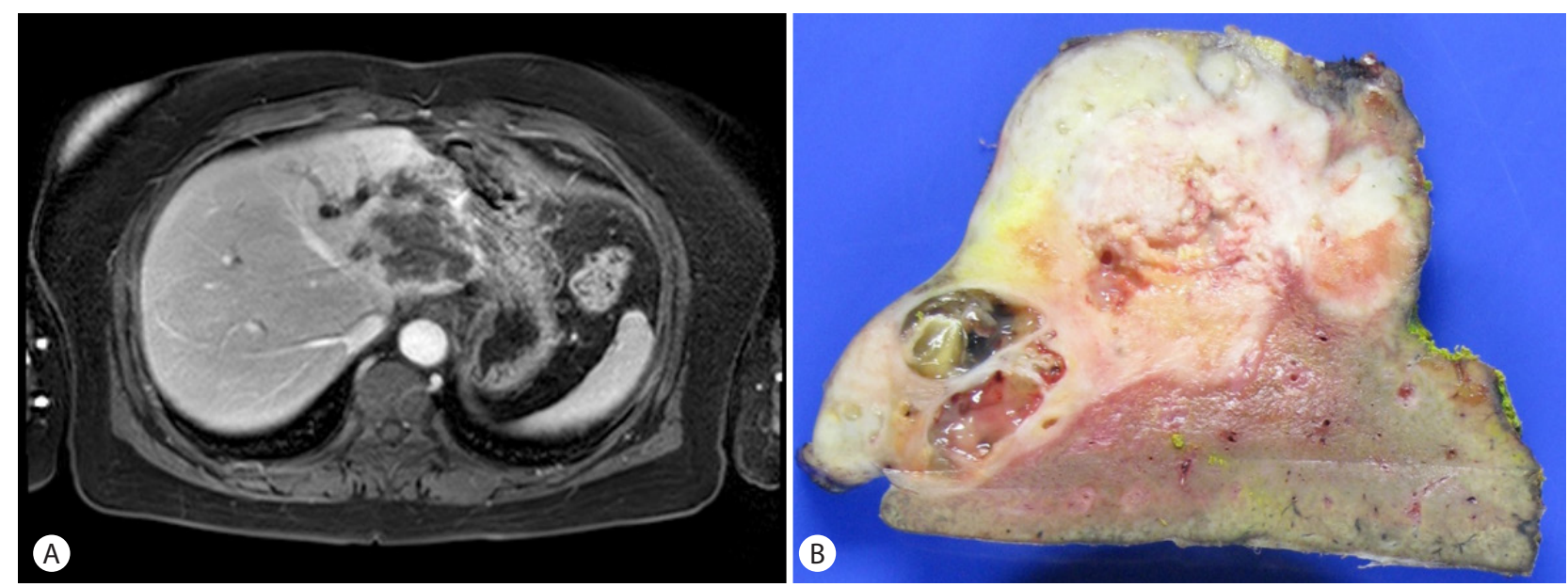

Figure 1. Imaging and gross pathologic findings of the tumor. (A) Gadolinium-enhanced magnetic resonance imaging shows an ill-defined, low-signal-intensity mass with rim enhancement in the left lateral segment of the liver. (B) In the left hemihepatectomy specimen, the cut surface reveals a firm white-yellow mass with cystic change and necrosis.

aminotransferase (25 IU/L), serum alanine aminotransferase (20 $\mathrm{IU} / \mathrm{L})$, and total bilirubin $(0.6 \mathrm{mg} / \mathrm{dL})$ level were within normal limits. The CA19-9 was elevated to $433.9 \mathrm{U} / \mathrm{mL}$ (normal range, $<34$ $\mathrm{U} / \mathrm{mL}$ ) and the carcinoembryonic antigen was elevated to $13.6 \mathrm{ng} /$ $\mathrm{mL}$ (normal range, $<4.3 \mathrm{ng} / \mathrm{mL}$ ). The levels of alpha fetoprotein $(3.7 \mathrm{ng} / \mathrm{mL}$ ) and protein induced by vitamin $\mathrm{K}$ absence or antagonist II (18 mAU/mL) were within normal limits. Serological tests for hepatitis $B$ and hepatitis $C$ virus were negative.

Abdominal computed tomography and magnetic resonance imaging showed a $6.5 \times 6.0-\mathrm{cm}$ ill-defined mass occupying the left lateral segment of the liver and invading the left intrahepatic duct and left portal vein (Fig. 1A). There were several small lymph nodes in the hepatoduodenal and portocaval area. A 1.1-cm stone was noted in the distal CBD with diffuse biliary dilatation. Positron-emission tomography-computed tomography scan revealed an intense hypermetabolic mass with internal metabolic defect in the left lateral segment of the liver and lymph nodes with mild to moderate fluorodeoxyglucose uptake in the portocaval, hepatoduodenal, and anterior cardiophrenic area. Endoscopic retrograde cholangiopancreatography and endoscopic sphincterotomy were performed to remove a CBD stone. The patient underwent left hemihepatectomy with regional lymph node dissection following a clinical diagnosis of cholangiocarcinoma. The pathologic examination of the specimen revealed ASC, with pT2aN1 stage. The patient received postoperative chemoradiation therapy. Follow-up biliary computed tomography 8 months after surgery detected two peripheral enhancing nodules in the liver, suggesting probable recurrence of the tumor.

On gross examination, there was an ill-defined, firm white-yel- low mass $(6.5 \times 6.0 \times 4.0 \mathrm{~cm})$ with a necrotic area and cystic change (Fig. 1B). The tumor grossly invaded into the Glisson's capsule. Histologically, the tumor consisted of malignant glandular and squamous components within a fibrous stroma. The moderately differentiated glandular structures contained extracellular mucin, whereas the squamous differentiation showed irregular nests of polygonal cells with abundant keratin pearls and occasional intercellular bridges (Fig. 2A, B). The adenocarcinoma and squamous cell carcinoma components were intimately admixed with transitional areas (Fig. 2C). Lymphovascular invasion and perineural invasion were identified. Metastatic foci were observed in one lymph node (Fig. 2D). Squamous metaplasia of the benign bile ducts was not identified in the surrounding hepatic tissue. The residual tissue of the liver was not cirrhotic. Immunohistochemical results showed that cytokeratin 7 was diffuse and strongly positive in the glandular component but weakly positive in the squamous component (Fig. 2E). Expression of p63 was restricted to the squamous component (Fig. 2F). Cytokeratin 20 was negative in both components. Based on the histological and immunohistochemical findings, the diagnosis of ASC was made.

\section{DISCUSSION}

Primary hepatic ASC is a rare variant of cholangiocarcinoma. Since it was first reported as "adenosquamous carcinoma of the liver" by Barr and Hancock in 1975, about 73 cases have been published. Histologically, ASC exhibits two components: glandular (adenocarcinoma) and squamous (squamous cell carcinoma). The 
Kyung Han Nam, et al.
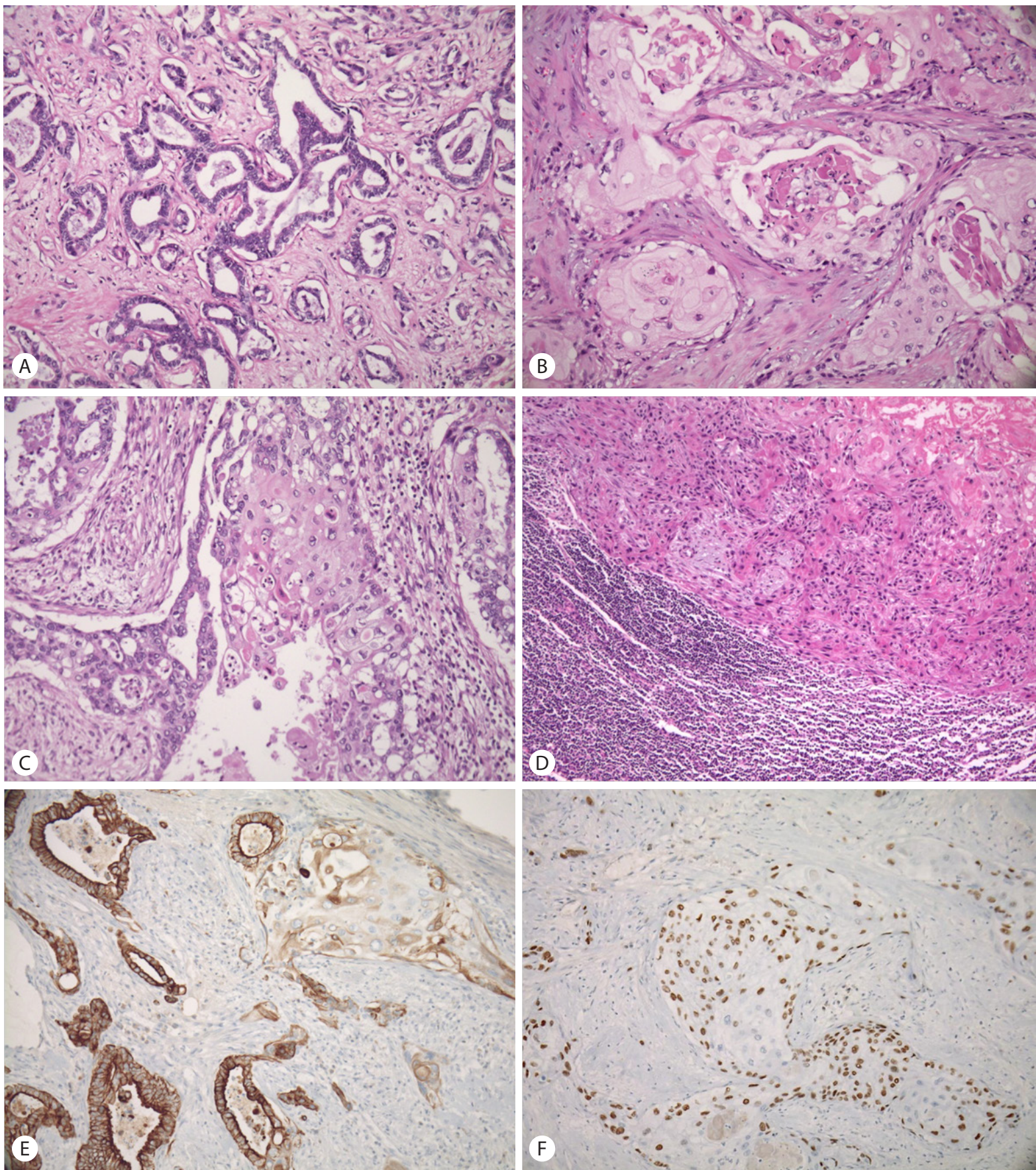

Figure 2. Histopathologic findings of adenosquamous carcinoma. (A) Adenocarcinoma component with malignant glands in a fibrous stroma. (B) Squamous cell carcinoma component with keratin pearl formation. (C) The transitional area between the two components shows mixed features. (D) Metastasis in lymph node. (A-D, hematoxylin and eosin stain, original magnification $\times 200$ ). (E) Cytokeratin 7 is strongly positive in the adenocarcinoma component and weakly positive in the squamous cell carcinoma component. (F) p63 is positive in squamous cell carcinoma component (E and F, immunohistochemistry, original magnification ×200).

adenocarcinoma component is formed by variable-sized glandular structures containing intracellular and extracellular mucin, whereas the squamous cell carcinoma component is characterized by ir- regularly shaped solid and nests of polygonal cells with distinct cellular border, eosinophilic cytoplasm, varying degrees of keratinization, and intercellular bridges. ${ }^{2,6}$ Cholangiocarcinoma with a 
Table 1. Clinicopathologic features of reported cases of primary hepatic adenosquamous carcinoma in Korea

\begin{tabular}{|c|c|c|c|c|c|c|c|c|}
\hline Authors & $\begin{array}{l}\text { Age }(y) / \\
\text { sex }\end{array}$ & Symptoms & $\begin{array}{l}\text { Localization/ } \\
\text { size }(\mathrm{cm})\end{array}$ & $\begin{array}{c}\text { Radiologic } \\
\text { diagnosis }\end{array}$ & $\begin{array}{l}\text { Preoperative } \\
\text { biopsy }\end{array}$ & Metastasis & Treatment & Outcome \\
\hline $\begin{array}{l}\text { Ahn et al. } \\
(1994)^{12}\end{array}$ & $62 / M$ & $\begin{array}{l}\text { Abdominal } \\
\text { pain, fever }\end{array}$ & $\begin{array}{l}\text { Segment } 4 \\
5 / 12 \times 10 \times 10\end{array}$ & $\begin{array}{l}\text { Liver abscess, } \\
\text { cholecystitis }\end{array}$ & Not done & Lymph node & $\begin{array}{l}\text { Segmentectomy, } \\
\text { cholecystectomy }\end{array}$ & NA \\
\hline $\begin{array}{l}\text { Lee et al. } \\
(1997)^{13}\end{array}$ & $72 / F$ & $\begin{array}{l}\text { Abdominal } \\
\text { pain }\end{array}$ & Left lobe/7 & Hepatic cysts & ASC & $\begin{array}{l}\text { Intrahepatic, } \\
\text { lymph node }\end{array}$ & NA & NA \\
\hline $\begin{array}{l}\text { Lee et al. } \\
(1999)^{14}\end{array}$ & $49 / M$ & $\begin{array}{l}\text { Abdominal } \\
\text { pain, fever }\end{array}$ & $\begin{array}{l}\text { Right lobe/ } \\
\quad 8 \times 7.5\end{array}$ & Liver abscess & ASC & None & Right lobectomy & NA \\
\hline $\begin{array}{l}\text { Kwon et al. } \\
(2001)^{11}\end{array}$ & $63 / M$ & Fever & $\begin{array}{l}\text { Left lobe/ } \\
6 \times 5 \times 5\end{array}$ & Liver abscess & $\mathrm{CC}$ & None & $\begin{array}{l}\text { Left lobectomy and } \\
\text { chemotherapy }\end{array}$ & $\begin{array}{l}\text { Alive } 8 \text { months } \\
\text { after surgery }\end{array}$ \\
\hline $\begin{array}{l}\text { Gu et al. } \\
(2005)^{15}\end{array}$ & $60 / F$ & $\begin{array}{l}\text { Abdominal } \\
\text { pain }\end{array}$ & Left lobe/3 & $\begin{array}{c}\text { CC with } \\
\text { hepatolithiasis }\end{array}$ & $\mathrm{CC}$ & Lymph node & Left lobectomy & NA \\
\hline $\begin{array}{l}\text { Shin et al. } \\
(2006)^{16}\end{array}$ & $54 / M$ & $\begin{array}{l}\text { Abdominal } \\
\text { pain, weight } \\
\text { loss }\end{array}$ & $\begin{array}{l}\text { Right lobe/ } \\
10 \times 9 \times 9\end{array}$ & $\begin{array}{l}\text { Tumor-colonic } \\
\text { fistula }\end{array}$ & SCC & Intrahepatic & $\begin{array}{l}\text { Right lobectomy, } \\
\text { microwave } \\
\text { coagulation and right } \\
\text { hemicolectomy }\end{array}$ & $\begin{array}{l}\text { Lung } \\
\text { metastasis, } \\
\text { died } 6 \text { months } \\
\text { after surgery }\end{array}$ \\
\hline $\begin{array}{l}\text { Bang et al. } \\
(2007)^{17}\end{array}$ & $69 / M$ & None & $\begin{array}{l}\text { Segment 3/ } \\
1.3 \times 1.2\end{array}$ & $\begin{array}{l}\text { Metastasis } \\
\text { from colon } \\
\text { cancer }\end{array}$ & Not done & None & $\begin{array}{l}\text { Segmentectomy and } \\
\text { chemotherapy }\end{array}$ & $\begin{array}{l}\text { Alive, recurred } \\
3 \text { months after } \\
\text { surgery }\end{array}$ \\
\hline $\begin{array}{l}\text { Park et al. } \\
(2012)^{6}\end{array}$ & $67 / M$ & $\begin{array}{l}\text { Abdominal } \\
\text { discomfort }\end{array}$ & $\begin{array}{l}\text { Right lobe/ } \\
\text { NA }\end{array}$ & $\begin{array}{l}\text { Multiple } \\
\text { masses }\end{array}$ & Not done & None & Trisegmentectomy & $\begin{array}{l}\text { Died } 2 \text { days } \\
\text { after surgery }\end{array}$ \\
\hline $\begin{array}{l}\text { Kang et al. } \\
(2013)^{18}\end{array}$ & $73 / \mathrm{M}$ & None & $\begin{array}{l}\text { Left lobe/ } \\
5 \times 5\end{array}$ & $\mathrm{CC}$ & Not done & Lymph node & $\begin{array}{l}\text { Left hemihepatectomy } \\
\text { and caudate lobectomy }\end{array}$ & $\begin{array}{l}\text { Alive } 15 \text { months } \\
\text { after surgery }\end{array}$ \\
\hline $\begin{array}{l}\text { Present } \\
\text { case }\end{array}$ & $56 / F$ & $\begin{array}{l}\text { Abdominal } \\
\text { pain }\end{array}$ & $\begin{array}{l}\text { Left lobe/ } \\
6.5 \times 6 \times 4\end{array}$ & $\mathrm{CC}$ & Not done & Lymph node & $\begin{array}{l}\text { Left hemihepatectomy } \\
\text { and chemoradiation } \\
\text { therapy }\end{array}$ & $\begin{array}{l}\text { Alive, recurred } \\
8 \text { months after } \\
\text { surgery }\end{array}$ \\
\hline
\end{tabular}

y, years; NA, not applicable; ASC, adenosquamous carcinoma; CC, cholangiocarcinoma; SCC, squamous cell carcinoma.

squamous differentiation have been previously described as ASC, mucoepidermoid carcinoma, and adenoacanthoma. ${ }^{2,7}$ However, the histological features of ASC allow us to distinguish it from other neoplasms. Mucoepidermoid carcinoma is usually composed of mucus-producing cells, intermediate cells, and squamoid (epidermoid) cells lacking keratin formation. ${ }^{2}$ Adenoacanthoma represents adenocarcinoma containing foci of benign-appearing squamous metaplasia. ${ }^{2}$ In the present case, the squamous component showed both cytologic atypia and prominent keratinization, which were interpreted as malignant cells, and intermediate cells were absent in this tumor.

The pathogenesis of ASC of the liver remains unclear. The two major hypotheses have been suggested. Chronic inflammation of the bile duct or hepatic cysts in association with infection and/or hepatolithiasis might cause squamous metaplasia of the benign epithelium and subsequent malignant transformation. ${ }^{8,9}$ Although ASC arising from hepatic cyst is uncommon, coexisting hepatic cysts with squamous epithelium were reported in three cases. ${ }^{2}$ Meanwhile, some authors suggested that ASC arises from the squamous metaplasia of preexisting adenocarcinoma because neither normal epithelium nor association with biliary cysts were found in the tumors. ${ }^{5,10}$ In addition, a previous study of ASC immunohistochemistry has revealed that both adenocarcinoma and squamous cell components were positive for cytokeratin 7, which indicates squamous change of the adenocarcinoma. ${ }^{4}$ In the analysis of 12 patients with hepatic ASC, Yeh et al. ${ }^{3}$ proposed that hepatolithiasis may play a role in the neoplastic transformation superimposed on the metaplastic change of ordinary cholangiocarcinoma. In the present case, the tumor was composed of only two malignant components, and squamous metaplasia of the biliary epithelium or preexisting biliary cyst was absent within the tumor. However, a CBD stone with diffuse biliary dilatation was observed in our case. Regarding these findings, the current ASC of the liver appears to have developed from the metaplastic change 
of the adenocarcinoma as well as associated with persistent inflammation accompanying the CBD stone.

The prognosis of patients with hepatic ASC has been reported to be extremely poor, even with surgery. ${ }^{1,2,4}$ Nakajima and Kondo ${ }^{1}$ revealed that 11 patients with cholangiocarcinoma with squamous component had a worse prognosis than 82 with common cholangiocarcinoma (4.0 01.2 versus $6.9 \pm 1.2$ months). The study by Maeda et al. ${ }^{4}$ of 6 surgically resected ASC patients showed similar results. Meanwhile, Yeh et al. ${ }^{3}$ noted that 10 patients with ASC had poor prognosis but had no significant difference in overall survival between ASC and common cholangiocarcinoma. Considering the limited data on this histologic subtype, further studies may be needed to clarify the proper clinical outcome of ASC compared to cholangiocarcinoma of pure adenocarcinoma. Kobayashi, et al. ${ }^{2}$ analyzed the clinicopathologic features of 42 patients with hepatic ASC in the literature from 1975 to 2005. According the study, the mean survival of 34 cases was 8.74 months. The mean age is 63.9 years, and 30 of 42 cases were male. The majority of patients complained of abdominal pain as initial symptom. Abdominal pain, fever, and jaundice were described to be the most frequent symptoms. Among 30 cases with surgical resection, 14 of 27 cases had lymph node metastasis and 8 of 29 cases had intrahepatic metastasis. In operated cases, lymph node metastasis and elevation in serum total bilirubin were significantly associated with poor prognosis. In the study, 12 cases of coexisting hepatobiliary disease were reported (4 cases with hepatic cyst, 1 with cystadenoma, 1 with cystadenocarcinoma, and 1 with hemangioma).

In Korea, 10 cases with primary hepatic ASC (including our case) have been reported (Table 1)..$^{6,11-18}$ The mean age of these cases was $62.5 \pm 7.9$ years and a male predominance was noted ( $M / F=7: 3)$. The common symptom is abdominal pain in 7 cases. The tumors were located in the left lobe in 6 cases and in the right lobe in 4 . Only 5 cases were histologically examined by needle biopsy. Two cases were diagnosed as ASC and 1 case was squamous cell carcinoma. Two of the 10 cases had coexistent hepatobiliary disease (multiple hepatic cysts and hepatolithiasis). Tumors presenting as liver abscess, presence of metachronous colon cancer, and presence of a fistula between the tumor and the colon were reported in 3, 1, and 1 case, respectively. The treatment of choice for this tumor is curative resection. ${ }^{11}$ Nine of the 10 cases underwent surgical resection and 3 cases received postoperative chemotherapy. Lymph node metastasis was found in 5 cases and intrahepatic metastasis in 2. In our case, the patient was treated with left lobectomy and postoperative chemoradiation therapy and had a recurrence within 8 months after operation.

\section{Acknowledgements}

The institutional review board of the Inje University Haeundae Paik Hospital approved this study (IRB File No. 2016-09-011), which was conducted according to the guidelines of the 1975 Declaration of Helsinki.

\section{Conflicts of Interest}

The authors have no conflicts to disclose.

\section{REFERENCES}

1. Nakajima T, Kondo Y. A clinicopathologic study of intrahepatic cholangiocarcinoma containing a component of squamous cell carcinoma. Cancer 1990;65:1401-1404.

2. Kobayashi M, Okabayashi T, Okamoto K, Namikawa T, Araki K. A clinicopathologic study of primary adenosquamous carcinoma of the liver. J Clin Gastroenterol 2005;39:544-548.

3. Yeh CN, Jan YY, Chen MF. Adenosquamous carcinoma of the liver: clinicopathologic study of 10 surgically treated cases. World I Surg 2003;27:168-172.

4. Maeda T, Takenaka K, Taguchi K, Kajiyama K, Shirabe K, Shimada $M$, et al. Adenosquamous carcinoma of the liver: clinicopathologic characteristics and cytokeratin profile. Cancer 1997;80:364-371.

5. Barr RJ, Hancock DE. Adenosquamous carcinoma of the liver. Gastroenterology 1975;69:1326-1330.

6. Park SY, Cha EJ, Moon WS. Adenosquamous carcinoma of the liver. Clin Mol Hepatol 2012;18:326-329.

7. Pianzola LE, Drut R. Mucoepidermoid carcinoma of the liver. Am J Clin Pathol 1971;56:758-761.

8. Gresham GA, Rue LW 3rd. Squamous cell carcinoma of the liver. Hum Pathol 1985;16:413-416.

9. Greenwood N, Orr WM. Primary squamous-cell carcinoma arising in a solitary non-parasitic cyst of the liver. J Pathol 1972;107:145-148.

10. Hamaya K, Nose S, Mimura T, Sasaki K. Solid adenosquamous carcinoma of the liver. A case report and review of the literature. Acta Pathol Jpn 1991;41:834-840.

11. Kwon OS, Lee HS, Koh DW, Cho YJ, Park YH, Park DK, et al. A case of primary adenosquamous carcinoma of the liver presented with liver abscess. Korean J Intern Med 2001;16:270-273.

12. Ahn KC, Ahn HS, So BJ, Chae KM. A case of adenosquamous carcinoma of the liver. Ann Surg Treat Res 1994;47:1034-1037.

13. Lee SJ, Lee Wj, Lim HK, Lim JH, Han BK, Ro DW, et al. Adenosquamous carcinoma of the liver: a case report. J Korean Radiol Soc 1997;36:129-131.

14. Lee YD, Jo CM, Kim DH, Kim HS, Kwon JG, Tag WY, et al. A case of primary adenosquamous cell carcinoma of liver presented with the clinical symptom of liver abscess. Korean J Hepatol 1999;5(Suppl 1):S103. 
15. Gu MJ, Choi JH, Park WK, Chang JC, Kim HJ. Primary adenosquamous carcinoma of the liver: a case report. Korean J Hepatol 2005;11:86-89.

16. Shin JU, Jung JT, You SS, Kwon JG, Kim EY, Lee CH, et al. A case of primary adenosquamous carcinoma of the liver with formation of colonic fistula. Korean J Gastroenterol 2006;48:360-364.
17. Bang WB, Lim MJ, Lim JH, Kim EJ, Jeong S, Choi SJ, et al. An adenosquamous carcinoma of the liver that developed metachronously in a patient with a colon adenocarcinoma. Korean J Intern Med 2007;72:74-78

18. Kang GH, Lee BS, Kang DY. A case of primary adenosquamous carcinoma of the liver. Korean J Hepatobiliary Pancreat Surg 2013;17:38-41. 